\title{
Congenital giant intramedullary spinal cord schwannoma
}

Figure Congenital schwannoma: MRI and histology
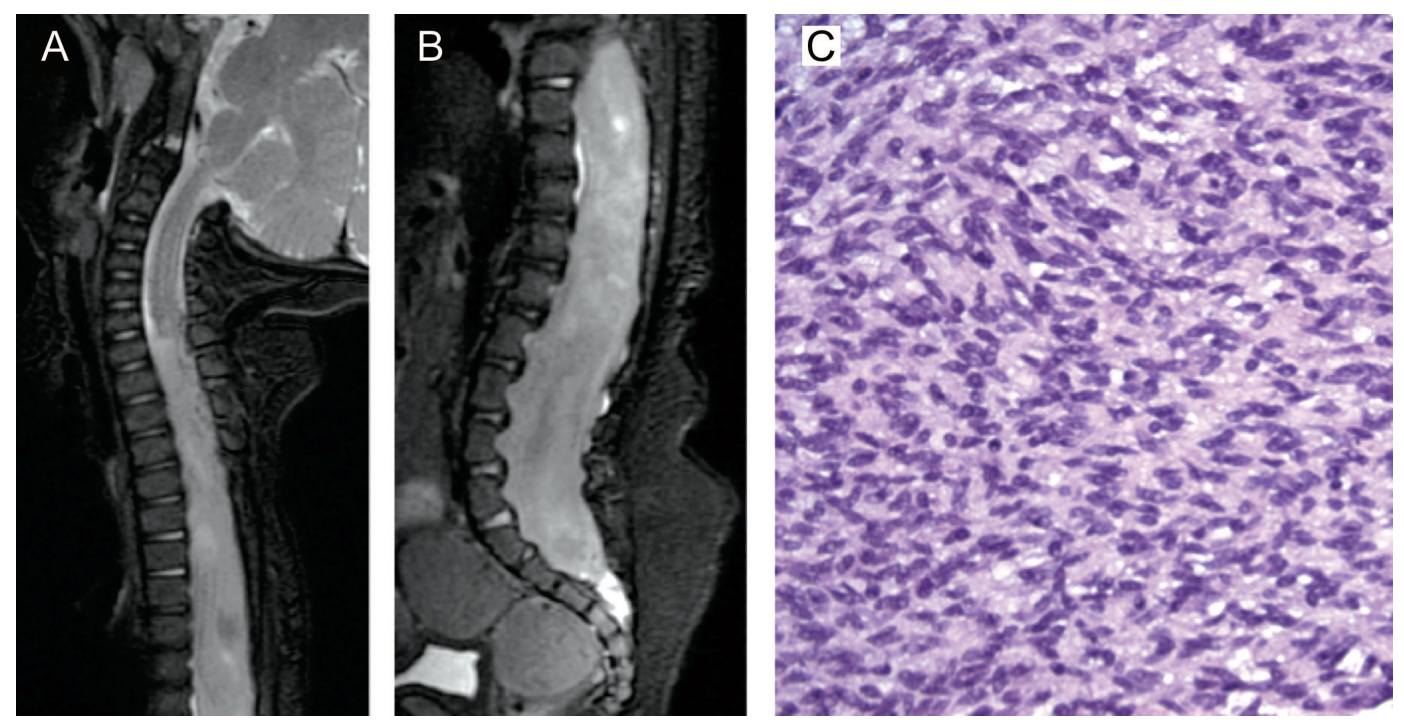

Sagittal T2-weighted spine MRI (A, B) demonstrates an intramedullary mass from T2 to the distal spinal column with extension through the neural foramina and scalloping along the lumbar vertebral bodies. Pathology revealed a benign spindle cell neoplasm with palisading of bland, vesicular nuclei consistent with a cellular schwannoma (C, 400× magnification).

A full-term infant with an uncomplicated vaginal delivery presented with absent cry on routine newborn heelstick testing. Neurologic examination revealed paraplegia, absent reflexes, and a T4 sensory level. Spinal MRI showed an expansive, gadolinium-enhancing intramedullary mass from T2 to the thecal sac (figure, A and B). Biopsy confirmed a diagnosis of cellular schwannoma, WHO grade 1 (figure, C). Genetic and immunohistochemical testing for NF-2 and schwannomatosis were negative. Cases of focal intramedullary schwannoma have been rarely reported. ${ }^{1,2}$ This congenital, extensive intramedullary schwannoma highlights the diversity of low-grade neonatal spinal neoplasms, obviating initiation of therapy until pathologic diagnosis is achieved.

C.A. Lyle, MD, D. Malicki, MD, PhD, M.O. Senac, MD, M.L. Levy, MD, PhD, J.R. Crawford, MD, MS,

San Diego, $C A$

Disclosure: Dr. Lyle, Dr. Malicki, and Dr. Senac report no disclosures. Dr. Levy serves on the editorial advisory boards of Neurosurgery, World Neurosurgery, and the Journal of Health Communication; serves on a scientific advisory board for and holds stock/stock options in Stemedica Cell Technologies, Inc.; and is listed as author on a patent re: Absorbable biowax (now owned by USC), for which he receives royalty payments from Childrens Hospital Los Angeles. Dr. Crawford reports no disclosures.

Address correspondence and reprint requests to Dr. Courtney Lyle, Department of Pediatrics, Division of Hematology-Oncology, University of California, San Diego, Rady Children's Hospital, 3020 Children's Way MC 5035, San Diego, CA 92123; calyle@rchsd.org

1. Kim NR, Suh YL, Shin HJ. Thoracic pediatric intramedullary schwannoma: report of a case. Pediatr Neurosurg 2009;45:396401.

2. Kodama Y, Terae S, Hida K, Chu BC, Kaneko K, Miyasaka K. Intramedullary schwannoma of the spinal cord: report of two cases. Neuroradiol 2001;43:567-571. 


\section{Neurology}

\section{Congenital giant intramedullary spinal cord schwannoma}

C.A. Lyle, D. Malicki, M.O. Senac, et al.

Neurology 2010;75;1752

DOI 10.1212/WNL.0b013e3181fc29f2

\section{This information is current as of November 8,2010}

\section{Updated Information \&} Services

References

Subspecialty Collections

Permissions \& Licensing

Reprints including high resolution figures, can be found at: http://n.neurology.org/content/75/19/1752.full

This article cites 2 articles, 0 of which you can access for free at: http://n.neurology.org/content/75/19/1752.full\#ref-list-1

This article, along with others on similar topics, appears in the following collection(s):

All Pediatric

http://n.neurology.org/cgi/collection/all_pediatric

All Spinal Cord

http://n.neurology.org/cgi/collection/all_spinal_cord

Neonatal

http://n.neurology.org/cgi/collection/neonatal

Spinal cord tumor

http://n.neurology.org/cgi/collection/spinal_cord_tumor

Information about reproducing this article in parts (figures,tables) or in its entirety can be found online at:

http://www.neurology.org/about/about_the_journal\#permissions

Information about ordering reprints can be found online:

http://n.neurology.org/subscribers/advertise

Neurology ${ }^{\circledR}$ is the official journal of the American Academy of Neurology. Published continuously since 1951, it is now a weekly with 48 issues per year. Copyright Copyright @ 2010 by AAN Enterprises, Inc.. All rights reserved. Print ISSN: 0028-3878. Online ISSN: 1526-632X.

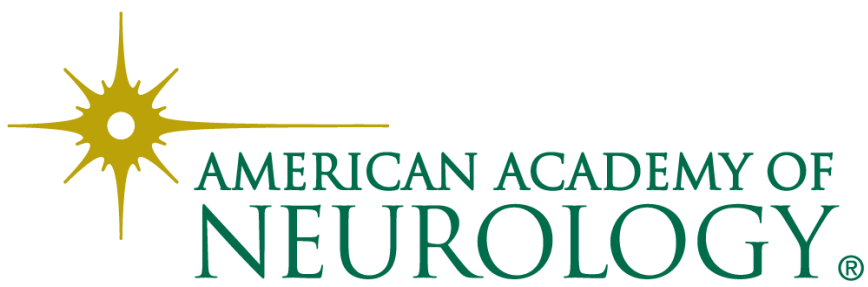

